\title{
Arctic Fisheries Conservation and Management: Initial Steps of Reform of the International Legal Framework
}

\author{
E.J. Molenaar*
}

\section{Abstract}

The dramatic impacts that global climate change are expected to have in the future also extend to Arctic marine capture fisheries. Arctic marine ecosystems will change in various ways and this is among other things likely to create new or expanded fishing opportunities. This article assesses the adequacy of the current international legal and policy framework for Arctic fisheries conservation and management - both substantively and institutionally - in responding to the likely and potential impacts that such new or expanded fishing opportunities could have on target and nontarget species, the broader marine ecosystem and the livelihoods of indigenous peoples. The overview of the international legal and policy framework that is offered in this article is followed by the identification of gaps in this framework and in national regulation, and of options for addressing them. These options include increased efforts in the sphere of research and data gathering, bilateral fisheries management arrangements between Arctic Ocean coastal states, a declaration on new and existing fisheries in the Arctic Ocean and a state-of-the-art regional fisheries management organisation (RFMO) or Arrangement. Finally, some observations are made on integrated, cross-sectoral ecosystem-based oceans management.

\footnotetext{
* Senior Research Associate, Netherlands Institute for the Law of the Sea (NILOS), Utrecht University and Adjunct Professor, Faculty of Law, University of Tromsø. The author can be contacted at: E.J.Molenaar@uu.nl. This paper builds on the author's contributions to the project 'Arctic TRANSFORM: Transatlantic Policy Options for Supporting Adaptations in the Marine Arctic', funded by the European Commission, Directorate-General External Relations (info at http://www.arctic-transform.eu). The author is grateful for the comments received on his contributions by other participants in the project.
} 


\section{Introduction}

It is now widely accepted that global climate change will have dramatic impacts for the Arctic. The rapid warming of the Arctic climate was the first and most prominent of the ten key findings of the 2004 Arctic Climate Impact Assessment (ACIA). ${ }^{1}$ On 15 September 2007, the Arctic ice cap was 22 percent below the last record set in 2005. ${ }^{2}$ This 2007 record exceeded the computer model predictions used to prepare the Intergovernmental Panel on Climate Change (IPCC) Fourth Assessment Report (AR4) in 2007. ${ }^{3}$ Perhaps even more important than ice-coverage as such, is the increasing percentage of first-year sea-ice. Many scientists fear that the 'Arctic meltdown' has become irreversible even though the 2007 record remained intact in 2008 .

Of particular importance to this article are ACIA's key findings No. 4: "Animal species' diversity, ranges and distribution will change" and No. 6: "Reduced sea ice is very likely to increase marine transport and access to resources". While the former predicts changes in the composition of the Arctic marine ecosystem in quantitative, qualitative, spatial and temporal terms, the latter predicts increased pressure on this ecosystem due to more intensive exercise of existing maritime uses (e.g. shipping and fishing) as well as new uses. ACIA's key finding No. 4 is among other things supported by sightings of species in higher latitudes than before and by indications that endemic species are adversely affected by recent changes in the Arctic. ${ }^{4}$

The aim of this article is to assess the adequacy of the current international legal framework for Arctic fisheries conservation and management in the context of global climate change. ${ }^{5}$ For the purpose of this article, the acronym regional fisheries management organisation (RFMO) is defined as a regional intergovernmental organisation with the competence to impose on its Members legally binding measures for the conservation and management of target fishery resources and regulating impacts of fishing on non-target species. The

1 The Overview Report and the Scientific Report are available at http://www.amap.no/acia.

${ }^{2}$ See info at National Snow and Ice Data Centre http://www.nsidc.org/arcticseaicenews.

${ }^{3}$ Arctic ice retreating more quickly than computer models project. (2007, April 30). NCAR News Release, available at http://www.ucar.edu/news/releases/2007/seaice.shtml.

${ }^{4}$ See R.G. Rayfuse, "Melting Moments: The Future of Polar Oceans Governance in a Warming World", Review of European Community and International Environmental Law 16 (2007): 196-216, at p. 202 and note 16 infra.

${ }^{5}$ For a discussion on Arctic marine shipping, see E.J. Molenaar, "Arctic Marine Shipping. Overview of the International Legal Framework, Gaps and Options", Journal of Transnational Law \& Policy (forthcoming in 2009). For a cross-sectoral discussion see T. Koivurova and E.J. Molenaar, "International Governance and Regulation of the Marine Arctic. Overview and Gap Analysis" (WWF, 2009;) available at http://www.panda.org/arctic. 
term 'Arrangement' is understood to be a bilateral or (sub-)regional cooperative mechanism other than an intergovernmental organisation, but otherwise has in principle the same characteristics as an RFMO. ${ }^{6}$

This article focuses exclusively on marine capture fisheries; aquaculture is therefore beyond its scope. As regards species, the article will often distinguish between fisheries for target species and the impacts of fisheries on non-target species. Target species are exclusively 'fishery resources', which are defined as fish, molluscs, crustaceans and sedentary species. ${ }^{7}$ Non-target species can be fishery resources and marine mammals but also birds and (other) benthic species, including corals. Even though fisheries are in this article approached from a sectoral perspective, the objective is to pursue an ecosystem approach to fisheries (EAF), defined in the FAO Technical Guidelines on 'The ecosystem approach to fisheries's as follows:

An ecosystem approach to fisheries strives to balance various societal objectives by taking into account the knowledge and uncertainties about biotic, abiotic and human components of ecosystems and their interactions and applying an integrated approach to fisheries within ecologically meaningful boundaries. ${ }^{9}$

More concrete, operationalised objectives of EAF include minimising or avoiding impacts of fishing on non-target species, for instance in terms of by-catch and ensuring availability of food in light of predator-prey relationships. These objectives complement the classic objectives of avoidance of over-exploitation of target species.

As a consequence of the predominantly sectoral perspective of this article, ${ }^{10}$ the focus will be exclusively on international instruments and intergovernmental and other relevant international bodies that relate to, or pursue, conservation as well as management. No attention will therefore be paid to

\footnotetext{
${ }^{6}$ The term 'Arrangement' is derived from the term 'arrangement' as defined in Art. 1(1)(d) of the Fish Stocks Agreement (Agreement for the Implementation of the Provisions of the United Nations Convention on the Law of the Sea of 10 December 1982 relating to the Conservation and Management of Straddling Fish Stocks and Highly Migratory Fish Stocks, New York, 4 August 1995. In force 11 December 2001, 34 ILM 1542 (1995); Also available at http://www.un.org/Depts/los.

${ }^{7}$ Based on Art. 1(b) of the NEAFC Convention (Convention on Future Multilateral Cooperation in the North-East Atlantic Fisheries, London, 18 November 1980. In force 17 March 1982, 1285 UNTS 129; See also http://www.neafc.org. 2004 Amendments (Art. 18bis), London; 12 November 2004. Not in force, but provisionally applied by means of the 'London Declaration' of 18 November 2005; 2006 Amendments, London (Preamble, Arts 1, 2 and 4), 11 August 2006. Not in force, but provisionally applied by means of the 'London Declaration' of 18 November 2005.

${ }^{8}$ FAO Technical Guidelines for Responsible Fisheries No. 4, Suppl. 2 (FAO, Rome: 2003).

9 At 6.

${ }^{10}$ See subsection on integrated, cross-sectoral ecosystem-based ocean management.
} 
those that focus exclusively on conservation of species and habitat by various means, including by the regulation of international trade.

In this article, the following are regarded as 'Arctic states': Canada, Denmark (in relation to Greenland), Finland, Iceland, Norway, the Russian Federation, Sweden and the United States. Even though there is no universally accepted definition for the 'Arctic Ocean', it seems generally accepted that there are only five coastal states to the Arctic Ocean, namely Canada, Denmark (in relation to Greenland), Norway, the Russian Federation and the United States. ${ }^{11}$

There is currently also no universally accepted definition for the spatial scope of the marine Arctic. Relevant instruments and processes use different definitions for the Arctic, for instance the area north of the northern treeline or the area north of the Arctic Circle (66 33' North). In this article, Arctic fisheries are regarded as the fisheries that occur in marine areas within the outer limits of the so-called 'AMAP area', as agreed by the Arctic Monitoring and Assessment Programme [sic] (AMAP) of the Arctic Council. ${ }^{12}$ These are the marine areas north of the Arctic Circle and north of $62^{\circ} \mathrm{N}$ in Asia and $60^{\circ} \mathrm{N}$ in North America, modified to include the marine areas north of the Aleutian chain, Hudson Bay, and parts of the North Atlantic Ocean including the Labrador Sea. For the purpose of this article, these marine areas are referred to as the 'Arctic marine area'.

It should be noted, however, that other relevant global international organisations have opted either explicitly or implicitly for different definitions of the Arctic or the marine Arctic. For instance, FAO (United Nations Food and Agriculture Organisation) Statistical Area No. 18: 'Arctic Sea', comprises Hudson Bay and adjacent waters, waters within the Canadian Arctic Archipelago and all of the Arctic Ocean, except the Atlantic sector. ${ }^{13}$

The article continues with section 2 on current Arctic fisheries, followed by section 3 on Arctic fisheries and climate change. Section 4 gives a concise overview of the law of the sea in the Arctic marine area. Subsequently, section 5 offers an overview of the international legal and policy framework with respect to Arctic fisheries management and section 6 devotes some attention to national regulation. Section 7 focuses on the gaps in the international legal and policy framework and national regulation and options for addressing them. The article ends with some conclusions in section 8 .

${ }^{11}$ This can for instance be deduced from the Ilulissat Declaration (Ilulissat, 28 May 2008 (available at http://www.arctic-council.org.

12 A map of the AMAP area is available at http://www.amap.no.

${ }^{13}$ A map of FAO Statistical Area No. 18 'Arctic Sea' can be found at http://www.fao.org/fishery/area/Area18. 


\section{Current Arctic Fisheries}

The broad spatial scope of the Arctic marine area (see above) implies that it includes a wide range of different ecosystems, fish stocks and fisheries. Significant differences exist for instance between the Atlantic and Pacific sides of the Arctic marine area. Cognisant of these differences, Chapter 13 on 'Fisheries and Aquaculture' of the ACIA Scientific Report opts to focus on the four major Arctic and Subarctic marine fisheries and their ecosystems, namely (i) the Northeast Atlantic (Barents and Norwegian Seas) (ii) the Central North Atlantic (waters around Iceland and off East Greenland), (iii) Northeast Canada (Newfoundland and Labrador Seas) and (iv) the North Pacific (Bering Sea). ${ }^{14}$

The species on which this ACIA chapter focuses are "those few circumpolar species (capelin (Mallotus villosus), Greenland halibut (Reinhardtius hippoglossoides), northern shrimp (Pandalus borealis), and polar cod (Boreogadus saida)) and those of commercial importance in specific regions. The latter include Atlantic cod (Gadus morhua), haddock (Melanogrammus aeglefinus), Alaska pollock (Theragra chalcogramma), Pacific cod (Gadus macrocephalus), snow crab (Chionoecetes opilio)" ${ }^{15}$ Other species discussed by the ACIA include herring, salmon and (red) king crab. It is nevertheless clear that these species are merely a selection, based to a considerable extent on the focus on the four spatial areas mentioned above. Saying anything useful about the relative importance of fisheries for these species is impossible without going into a lot of detail. ${ }^{16}$ The ACIA chapter also notes the complexity of the functioning of Arctic marine ecosystems as well as the limitations and shortcomings of science. ${ }^{17}$ Presumably, a lot of data required for pursuing an EAF is also presently not available.

\footnotetext{
${ }^{14}$ Also see the information in Chapter 12, entitled 'Hunting, Herding, Fishing, and Gathering: Indigenous Peoples and Renewable Resource Use in the Arctic', for instance on p. 652.

${ }_{15}$ ACIA, Scientific Report, Chapter 13, p. 693.

${ }^{16}$ For such detailed information see ACIA, Scientific Report, Chapter 13 and the North Pacific Fishery Management Council (NPFMC) Public Review Draft Fishery Management Plan for Fish Resources of the Arctic Management Area (Draft Arctic FMP), version of January 2009 and the Public Review Draft Environmental Assessment / Regulatory Impact Review / Initial Regulatory Flexibility Analysis for the Arctic Fishery Management Plan (Arctic FMP EA/RIR/IRFA Public Review Draft), version of January 2009, available at http://www.fakr. noaa.gov/npfmc. Other information can be obtained through the Arctic Fisheries Working Group operating under the International Council for the Exploration of the Sea (ICES; see http://www.ices.dk>). This working group, however, has so far been focusing exclusively on the Northeast Atlantic. See also W.E. Schrank, "The ACIA, Climate Change and Fisheries" Marine Policy 31 (2007): 5-18.

${ }^{17}$ ACIA, Scientific Report, Chapter 13: 692.
} 
The ACIA does not examine subsistence fisheries in the Arctic marine area under a separate heading, but devotes attention to them within the scope of the four spatial areas mentioned above. It seems likely, however, that subsistence fishing in other parts of the Arctic marine area will be relatively more important to indigenous peoples.

\section{Arctic Fisheries and Climate Change}

The following seem to be the main consequences of climate change to the Arctic marine area:

- much more rapid warming of Arctic surface temperatures in comparison with the rest of the world. As a consequence, Arctic waters will warm more rapidly as well;

- substantial reductions of Arctic sea ice coverage and thickness;

- reduced salinity due to influx of fresh water as a consequence of melting sea ice (which is essentially salt free) and glacial ice;

- other oceanographic and meteorological changes (e.g. more storms and waves) in particular due to changes in air and water temperature and sea ice coverage; and

- increasing acidification of the world's oceans due to increasing uptake of $\mathrm{CO}_{2}$ (which is not just relevant to the Arctic marine area).

That these changes will affect Arctic marine ecosystems is certain, but accurate predictions cannot be made. ${ }^{18}$ One general conclusion is that:

a moderate warming will improve the conditions for some of the most important commercial fish stocks, as well as for aquaculture. This is most likely to be due to enhanced levels of primary and secondary production resulting from reduced sea-ice cover and more extensive habitat areas for subarctic species such as cod and herring. Global warming is also likely to induce an ecosystem regime shift in some areas, resulting in a very different species composition. ${ }^{19}$

The composition of Arctic marine ecosystems will undoubtedly change, both qualitatively and quantitatively. Some species will at some stage disappear and others (e.g. due to northward migration) will be added and the relative importance of species in abundance will change as well. These changes will of course be spatially and temporally differentiated. Where new fishing opportunities will occur (on the high seas or within coastal state maritime zones)

\footnotetext{
18 Ibid., at 770 .

${ }^{19}$ Ibid. One area in which an ecosystem shift occurred in the past is the Bering Sea.
} 
and with respect to which species or categories of species (e.g. shared, anadromous, straddling or highly migratory ${ }^{20}$ is also difficult to predict. Similarly which states - Arctic Ocean coastal states or other states - will benefit or suffer and how subsistence fishing will be affected, among other things by competition with commercial fisheries. Finally, as reduced ice overage and thickness will also enable other human activities - most importantly shipping and offshore hydrocarbon activities - these activities may compete with fishing in a spatial sense or affect them by pollution and other impacts.

The impact of current and future Arctic fisheries on the marine environment and marine biodiversity in the Arctic is not likely to be fundamentally different from impacts to the marine environment and biodiversity in other parts of the globe. Arctic fisheries could lead to over-exploitation of target species and a variety of impacts on non-target species, for instance on dependent species due to predator-prey relationships, on associated species due to by-catch and on benthic species due to bottom fishing techniques. ${ }^{21}$ In view of the broad spatial scope of the Arctic marine area, such undesirable effects are without doubt already occurring, even though not necessarily on a very serious scale.

\section{The Law of the Sea in the Arctic Marine Area}

The cornerstones of the current international law of the sea are the LOS Convention and its two implementation agreements, the Part XI Deep-Sea Mining Agreement ${ }^{22}$ and the Fish Stocks Agreement. ${ }^{23}$ The current international law of the sea applies to the marine environment of the entire globe; including therefore the entire marine environment of the Arctic Ocean, however defined.

The LOS Convention's overarching objective is to establish a universally accepted, just and equitable legal order - or 'Constitution' - for the oceans that lessens the risk of international conflict and enhances stability and peace in the international community. The LOS Convention currently has 157 parties, the Part XI Deep-Sea Mining Agreement 135 parties and the Fish Stocks Agreement 75 parties. All Arctic states are parties to these three treaties, except for the United States, which is not a party to either the LOS

\footnotetext{
${ }^{20}$ See subsection 5.e on the LOS Convention.

${ }^{21}$ See subsection 5.e on the LOS Convention.

${ }^{22}$ Agreement relating to the Implementation of Part XI of the United Nations Convention on the Law of the Sea of 10 December 1982, New York, 28 July 1994. In force 28 July 1996, 33 ILM 1309 (1994); See also http://www.un.org/Depts/los.

${ }^{23}$ See note 6 supra.
} 
Convention or the Part XI Deep-Sea Mining Agreement. ${ }^{24}$ The European Community (EC) is party to all three treaties. This is important in view of the fact that Denmark, Finland and Sweden are Member States of the European Union (EU) ${ }^{25}$ and Iceland and Norway are parties to the EEA Agreement. ${ }^{26}$

The LOS Convention recognises the sovereignty, sovereign rights, freedoms, rights, jurisdiction and obligations of states within several maritime zones. The most important of these for the Arctic are internal waters, territorial sea, exclusive economic zone (EEZ), continental shelf, high seas and the 'Area'. ${ }^{27}$ Internal waters lie landward of the baselines. The maximum breadth of the territorial sea is 12 nautical miles ( $\mathrm{nm} ; 1 \mathrm{~nm}=1,852$ metres) measured from the baselines, $24 \mathrm{~nm}$ the maximum breadth for the contiguous zone and 200 $\mathrm{nm}$ for the EEZ. However, in many geographical settings these maximum breadths cannot be reached due to the proximity of the baselines of opposite states. In such circumstances maritime boundaries have to be agreed on by opposite states. Several of such maritime boundaries have already been established in the Arctic Ocean and negotiations on several others are still ongoing.

The LOS Convention recognises the sovereignty of a coastal state over its internal waters, archipelagic waters and territorial sea, the airspace above and its bed and subsoil. Sovereignty entails exclusive access and control of living and non-living resources and all-encompassing jurisdiction over all human activities, unless states have in one way or another consented to restrictions thereon. The LOS Convention also recognises specified economic and resource-related sovereign rights and jurisdiction of a coastal state with respect to its EEZ and (where relevant) outer continental shelf. Nevertheless, other states have navigational rights or freedoms within the maritime zones of coastal states and, with respect to their EEZ and (where relevant) outer continental shelf, also the freedoms of overflight, laying of submarine cables and pipelines and "other internationally lawful uses of the sea related to these freedoms". ${ }^{28}$

Article 76 of the LOS Convention also recognises that in certain circumstances the continental shelf extends beyond $200 \mathrm{~nm}$ from the baselines. This is the so-called 'outer continental shelf. Coastal states that take the view that

\footnotetext{
${ }^{24}$ Information obtained from http://www.un.org/Depts/los (accessed 9 February 2009).

${ }^{25}$ Even though EU membership of Denmark does not encompass Greenland.

${ }^{26}$ Agreement on the European Economic Area, Brussels, 17 March 1993. In force 1 January 1994; See also http://www.efta.int. Note that the EEA Agreement does not apply to Svalbard.

${ }^{27}$ Art. 1(1)(1) of the LOS Convention defines 'Area' as "the seabed and ocean floor and subsoil thereof, beyond the limits of national jurisdiction".

${ }^{28}$ Art. 58(1) of the LOS Convention.
} 
they have an outer continental shelf, must submit information on its outer limits on the basis of the criteria in Article 76 to the Commission on the Limits of the Continental Shelf (CLCS). The limits of the outer continental shelf established by the coastal state "on the basis of" the recommendations of the CLCS "shall be final and binding." ${ }^{29}$ So far, only the Russian Federation and Norway have made submissions to the CLCS in relation to their outer continental shelves that lie within the Arctic Ocean. The CLCS has up until now only made an interim recommendation in relation to the submission of the Russian Federation. The CLCS essentially recommended the Russian Federation to make a revised submission as regards the central Arctic Ocean basin. The Russian Federation is expected to do this in 2010. Canada, Denmark (in relation to Greenland) and the United States are all engaged in activities to enable them to make submissions to the CLCS, despite the fact that the United States is not yet party to the LOS Convention..$^{30}$ Canada has to make its submission by December 2013 and Denmark by December 2014. ${ }^{31}$ It should be noted that it is likely that there will be two pockets of the Area in the central Arctic Ocean.

There are four high seas pockets (enclaves) in the AMAP area. These are the so-called 'Banana Hole' in the Norwegian Sea, the so-called 'Loop Hole' in the Barents Sea, the so-called 'Donut Hole' in the central Bering Sea and the central Arctic Ocean. In the high seas, all states have the freedoms already mentioned above as well as the freedom to construct artificial islands and other installations, the freedom of fishing and the freedom of scientific research. These freedoms are all subject to conditions and obligations. ${ }^{32}$ The Area and its resources are the common heritage of mankind and the International Sea-bed Authority (ISA) is charged with organising and controlling all activities of exploration for, and exploitation of, the resources of the Area. ${ }^{33}$

The Treaty of Spitsbergen ${ }^{34}$ grants sovereignty over Svalbard to Norway and there seems to be increasingly less opposition by other states to Norway's entitlement to establish an EEZ and outer continental shelf off Svalbard. Disagreement still exists, however, on the way in which these sovereign

${ }^{29}$ Art. 76(8) of the LOS Convention.

${ }^{30}$ See the United States Arctic Region Policy (National Security Presidential Directive/NSPD66 \& Homeland Security Presidential Directive/HSPD-25, of 9 January 2009. In effect same day; text at http://www.whitehouse.gov (accessed 26 February 2009) (press release of 12 January 2009)), at Section D(4)(a).

${ }^{31}$ Cf. Art. 4 of Annex II to the LOS Convention.

${ }^{32}$ Art. 87(1) of the LOS Convention.

${ }^{33}$ Arts 1(1)(3), 136 and 157(1) of the LOS Convention.

${ }^{34}$ Treaty on the Status of Spitsbergen, Paris, 9 February 1920. In force 14 August 1925; 2 League of Nations Treaty Series 8. 
rights and jurisdiction granted to coastal states under the LOS Convention should be exercised in light of the equal rights accorded to parties to the Treaty of Spitsbergen. ${ }^{35}$

The fact that the current international law of the sea applies to the entire marine Arctic, however defined, is also emphasised by the five Arctic Ocean coastal states in the Ilulissat Declaration. ${ }^{36}$ Accordingly, as the "law of the sea" is an "extensive international legal framework", they "therefore see no need to develop a new comprehensive international legal regime to govern the Arctic Ocean". Conversely, they recognise the need for "appropriate measures" as a consequence of "developments in the Arctic Ocean". In the less than a single page text that follows, reference is among other things made to the safety of navigation, vessel-source pollution and contingency planning and emergency response to incidents with shipping and offshore exploitation. Notably, no mention is made of international fisheries instruments, fisheries management in general or the need for holistic, integrated or cross-sectoral governance or management.

It is worth noting that the Ilulissat Declaration refers to the "law of the sea" but not explicitly to the LOS Convention. This is hardly surprising as the United States is not a party to the LOS Convention. It is well-known that the United States takes the view that, except for its Part XI, the LOS Convention is already part of customary international law and in that way creates rights and obligations for the United States. However, while the United States does not also explicitly except the dispute settlement mechanism in Part XV of the LOS Convention from its statement on customary international law, this mechanism is not able to become part of that body of law as a consequence of its procedural nature. ${ }^{37}$ The dispute settlement mechanism in Part XV is widely regarded as a critical component of the package-deal that paved the way for the adoption of the LOS Convention. The fact that it provides for compulsory third party dispute settlement entailing binding decisions in many scenarios was a novelty in international law at the time. It thereby helps to safeguard the preservation of the package-deal of the LOS Convention by undesirable applications and interpretations of its provisions. The non-applicability of the dispute settlement mechanism of Part XV of the LOS Convention as between Arctic Ocean coastal states is therefore a

\footnotetext{
${ }^{35}$ See in this regard the Notes Verbales by Spain and the Russian Federation in response to the Norwegian submission to the CLCS in 2006 available at http://www.un.org/Depts/los (accessed 26 February 2009.

${ }^{36}$ See note 11 supra.

${ }^{37}$ Cf. T.L. McDorman, "Global Ocean Governance and International Adjudicative Dispute Resolution", Ocean and Coastal Management 43 (2000):255-275, at 259.
} 
significant gap in the "extensive international legal framework" referred to in the Ilulissat Declaration.

\section{International Legal and Policy Framework for Arctic Fisheries Management}

\section{a. Introduction}

The aim of this section is to provide an overview of the international legal and policy framework with respect to Arctic fisheries. The ensuing subsections address intergovernmental and other relevant international bodies and international instruments.

\section{b. Interests, Rights, Obligations and Jurisdiction}

The international legal and policy framework for fisheries conservation and management seeks to safeguard the different interests of the international community as a whole with those of states that have rights, obligations or jurisdiction in their capacities as flag, coastal, port or market states or with respect to their natural and legal persons. While the term 'flag state' is commonly defined as the state in which a vessel is registered and/or whose flag it flies ${ }^{38}$ there are no generally accepted definitions for the terms 'coastal state' or 'port state'. For the purpose of this background paper, however, the term 'coastal state' refers to the rights, obligations and jurisdiction of a state within its own maritime zones over foreign vessels. Conversely, the term 'port state' refers to the rights, obligations and jurisdiction of a state over foreign vessels that are voluntarily in one of its ports. The rights, obligations and jurisdiction of a port state do not overlap with those of a coastal state (e.g. port states would have jurisdiction over illegal fishing that has occurred beyond the coastal state's maritime zones, ${ }^{39}$ as well as over violations of conditions for entry into port).

In the context of this article, a port state's jurisdiction relates to fishing activities that have taken place beyond its maritime zones. Such fishing activities may nevertheless have related to transboundary stocks that also occur in the maritime zones of the port's coastal state. While there is no universally

\footnotetext{
${ }^{38}$ See e.g. Art. 91(1) of the LOS Convention.

39 This reasoning is predominantly based on Art. 218 of the LOS Convention. For a more comprehensive discussion see E.J. Molenaar, "Port State Jurisdiction: Towards Comprehensive, Mandatory and Global Coverage”, Ocean Development \& International Law 38 (2007): 225-257.
} 
accepted definition for the term 'market state', this paper uses the definition for this term proposed in the constitutive instrument of an RFMO under negotiation, namely "a State [...] which imports, exports, re-exports or has a domestic market for fish or fish products derived from fishing in the Convention Area". 40

Both flag and coastal states would in principle have an interest in longterm exercise of their entitlements over marine living resources in the various maritime zones. However, as a coastal state has exclusive access to marine living resources within areas under its national jurisdiction, its commitment to that objective may often be stronger than that of a flag state. A port state will commonly pursue socio-economic interests related to the port and its 'hinterland'. States generally have interests, rights, obligations and jurisdiction in more than one capacity. This often leads to a more balanced compromise position but occasionally also to contradictory positions of the same state within different fora. There is no reason or indication to assume that Arctic states are different in this regard. The interests of the international community normally overlap with those of the various capacities in which a state can act but are usually broader and more general. The interests of some states, however, clearly undermine those of other states and the international community. For instance by not ensuring that their ships comply with international minimum standards or by allowing foreign vessels in their ports to be in non-compliance with international minimum standards. These states, vessels and ports thereby have a competitive advantage over states, vessels and ports that do comply with international minimum standards. Such 'free riders' clearly benefit from the consensual nature of international law - meaning that a state can only be bound to a rule of international law when it has in one way or another consented to that rule.

\section{c. Substantive Standards}

Fisheries conservation and management authorities often make use of the following substantive standards:

- Restrictions on catch and effort, for instance by setting the total allowable catch (TAC) and allocating the TAC by means of national quotas;

- Minimum size limits for target species;

${ }^{40}$ Art. 1(m) of the Draft Convention on the Conservation and Management of High Seas Fishery Resources in the South Pacific Ocean (doc. SP/06/WP1, Revision 4 (October 2008), text at http://www.southpacificrfmo.org (accessed 26 February 2009). 
- Maximum by-catch limits, for instance in terms of the number of individuals (e.g. in relation to marine turtles and marine mammals) or as a percentage of the target catch;

- Technical measures, for instance minimum mesh sizes, by-catch mitigation techniques (e.g. turtle excluder devices, bird-scaring lines); and

- Spatial measures (e.g. closed areas) aimed at avoiding catch of target species (e.g. nursing and spawning areas) or non-target species (e.g. important feedings areas) or avoiding impact on sensitive habitat (e.g. cold water coral reefs).

\section{d. Intergovernmental and Other Relevant International Bodies}

The main global intergovernmental organisations and bodies of relevance to this paper are the United Nations General Assembly (UNGA) and the FAO. At the regional level, there are a number of RFMOs and bilateral or regional organisations/arrangements whose spatial scope overlaps to some extent with the Arctic marine area. These are:

- the International Commission on the Conservation of Atlantic Tunas (ICCAT), established by the ICCAT Convention; ${ }^{41}$

- the bilateral (Canada and the United States) International Pacific Halibut Commission (IPHC), established by the IPHC Convention; ${ }^{42}$

- the bilateral (Russian Federation and the United States) Intergovernmental Consultative Committee (ICC), established by the Agreement on Mutual Fisheries Relations; ${ }^{43}$

${ }^{41}$ International Convention for the Conservation of Atlantic Tunas, Rio de Janeiro, 14 May 1966. In force 21 March 1969, UNTS No. 9587 (1969); See also http://www.iccat.int.

${ }^{42}$ Convention for the Preservation of the Halibut Fishery of the North Pacific Ocean and the Bering Sea, Ottawa, 2 March 1953. In force 28 October 1953, 222 UNTS 78 (1955). Exchange of Notes Constituting an Agreement to Amend the [IPHC Convention], Washington, 29 March 1979. In force 29 March 1979, 1168 UNTS 380 (1980).

${ }^{43}$ Agreement between the Government of the United States of America and the Government of the Union of Soviet Socialist Republics on Mutual Fisheries Relations, Moscow, 31 May 1988. In force 28 October 1988, Treaties and other International Acts Series 11,422. The Agreement expires on 31 December 2008 but the United States will seek to extend it with another five years. The two states are currently engaged in negotiations to establish a comprehensive fisheries agreement for the Northern Bering Sea. At the 2007 ICC meeting, only three provisions of the draft agreement remained unresolved. The 2008 ICC meeting took place in September in the Russian Federation (information obtained from http://www.nmfs.noaa .gov/ia/bilateral, (accessed 3 August 2009). 
- the Northwest Atlantic Fisheries Organisation (NAFO), established by the NAFO Convention. ${ }^{44}$ Its main regulatory body is the NAFO Fisheries Commission;

- the North Atlantic Salmon Conservation Organisation (NASCO), established by the NASCO Convention; ${ }^{45}$

- the North East Atlantic Fisheries Commission (NEAFC), established by the NEAFC Convention; ${ }^{46}$

- the North Pacific Anadromous Fish Commission (NPAFC), established by the NPAFC Convention; ${ }^{47}$

- the Norway-Russian Federation Fisheries Commission (governed and established by the 1975 Framework Agreement, ${ }^{48}$ the 1976 Mutual Access Agreement ${ }^{49}$ and the 1978 Grey Zone Agreement ${ }^{50}$ ) and the trilateral Loophole Agreement and Protocols; ${ }^{51}$

${ }^{44}$ Convention on Future Multilateral Cooperation in the Northwest Atlantic Fisheries, Ottawa, 24 October 1978. In force 1 January 1979, 1135 UNTS 369; See also www.nafo.int. 2007 Amendment, Lisbon, 28 September 2007. Not in force, NAFO/GC Doc. 07/4. The 2007 Amendment consists of eight articles which replace the title with "Convention on Cooperation in the Northwest Atlantic Fisheries" and the existing Preamble, Annexes and almost all provisions by new ones.

${ }^{45}$ Convention for the Conservation of Salmon in the North Atlantic Ocean, Reykjavik, 2 March 1982. In force 1 October 1983, 1338 UNTS 33; See also http:www.nasco.int.

${ }^{46}$ Convention on Future Multilateral Cooperation in the North-East Atlantic Fisheries, London, 18 November 1980. In force 17 March 1982, 1285 UNTS 129; See also http://www .neafc.org. 2004 Amendments (Art. 18bis), London; 12 November 2004. Not in force, but provisionally applied by means of the 'London Declaration' of 18 November 2005; <www .neafc.org >. 2006 Amendments, London (Preamble, Arts 1, 2 and 4), 11 August 2006. Not in force, but provisionally applied by means of the 'London Declaration' of 18 November 2005.

${ }^{47}$ Convention for the Conservation of Anadromous Stocks in the North Pacific Ocean, Moscow, 11 February 1992. In force 16 February 1993, 22 Law of the Sea Bulletin 21 (1993); See also www.npafc.org.

${ }^{48}$ Agreement between the Government of Norway and the Government of the Union of Soviet Socialist Republics on Co-operation in the Fishing Industry, Moscow, 11 April 1975. In force 11 April 1975; 983 United Nations Treaty Series 7 (1975). See also O.S. Stokke, “The Loophole of the Barents Sea Fisheries Regime", in O.S. Stokke (ed) Governing High Seas Fisheries: The Interplay of Global and Regional Regimes, (Oxford University Press: 2001), 273-301, at 274.

${ }^{49}$ Agreement between the Government of the Union of Soviet Socialist Republics and the Government of the Kingdom of Norway Concerning Mutual Relations in the Field of Fisheries, Moscow, 15 October 1976. In force 21 April 1977; 1157 UNTS146 (1980).

${ }^{50}$ Avtale mellom Norge og Sovjetunionen om en midlertidig praktisk ordning for fisket i et tilstøtende område i Barentshavet, Oslo, 11 January 1978. In force 11 January 1978; Overenskomster med fremmede stater (1978), 436 (Agreement between Norway and the Soviet Union on provisional practical arrangements on fishing in an adjacent area of the Barents Sea).

${ }^{51}$ Agreement between the Government of Iceland, the Government of Norway and the Government of the Russian Federation Concerning Certain Aspects of Co-operation in the Area of 
- the Western and Central Pacific Ocean Fisheries Commission (WCPFC), established by the WCPFC Convention; ${ }^{52}$

- the Yukon River Panel of the bilateral (Canada and the United States) Pacific Salmon Commission (PSC), established by the Pacific Salmon Treaty; ${ }^{53}$ and

- the annual Conference of Parties (CoP) to the CBS Convention. ${ }^{54}$

Reference can also be made to the currently ongoing negotiation process for the establishment of an RFMO with competence over bottom fisheries in the Northwest Pacific. ${ }^{55}$ While interim measures adopted by this process apply south of $45^{\circ}$ North, no agreement has yet been reached on the spatial scope of the future Convention. ${ }^{56}$

The main Arctic Council working groups of relevance to this paper Conservation of Arctic Flora and Fauna (CAFF) and the Sustainable Development Working Group (SDWG). CAFF's work is guided by the CAFF Strategic Plan for the Conservation of Arctic Biological Diversity and has five core objectives, namely:

Fisheries, St. Petersburg, 15 May 1999. In force 15 July 1999; 41 Law of the Sea Bulletin 53 (1999); Protocol between the Government of Iceland and the Government of the Russian Federation under the Agreement between the Government of Iceland, the Government of Norway and the Government of the Russian Federation concerning Certain Aspects of Co-operation in the Area of Fisheries St. Petersburg, 15 May 1999. In force 15 July 1999; 14 International Journal of Marine and Coastal Law 488-490 (1999); See also http://www .faolex.fao.org; and Protocol between the Government of Norway and the Government of Iceland under the Agreement between the Government of Iceland, the Government of Norway and the Government of the Russian Federation concerning Certain Aspects of Cooperation in the Area of Fisheries St. Petersburg, 15 May 1999. In force 15 July 1999; 41 Law of the Sea Bulletin 56 (1999).

${ }^{52}$ Convention on the Conservation and Management of Highly Migratory Fish Stocks in the Western and Central Pacific Ocean, Honolulu, 5 September 2000. In force 19 June 2004, 40 ILM 277 (2001); See also http://www.wcpfc.int.

${ }^{53}$ Treaty between the Government of Canada and the Government of the United States of America Concerning Pacific Salmon, Ottawa, 28 January 1985. In force 18 March 1985; See also http://www.psc.org. The Yukon River Panel was established by means of the Yukon River Salmon Agreement of December 2002, which amended the Pacific Salmon Treaty.

${ }^{54}$ Convention on the Conservation and Management of Pollock Resources in the Central Bering Sea, Washington, 16 June 1994. In force 8 December 1995, 34 ILM 67 (1995); See also http://www.afsc.noaa.gov/refm/cbs.

${ }^{55}$ For some information see http://www.nwpbfo.nomaki.jpand Y. Takei, Filling Regulatory Gaps in High Seas Fisheries: Discrete High Seas Fish Stocks, Deep-Sea Fisheries and Vulnerable Marine Ecosystems ( $\mathrm{PhD}$ manuscript, Utrecht University, October 2008), at Chapter 5.3.

${ }^{56}$ Apparently, the Unites States does not favour the inclusion of the Bering Sea at all but Japan favours the inclusion of the high seas of the Bering Sea that fall within FAO Statistical Area No. 67. 
- Monitoring of Arctic biodiversity;

- Conservation of Arctic species \& their habitats;

- Consider the establishment of protected areas;

- Conservation of nature outside protected areas; and

- Integration of conservation objectives \& measures for economic sectors of the society;

Finally, reference can be made to the following relevant international bodies:

- the OSPAR Commission established under the OSPAR Convention, ${ }^{57}$ in particular for its work under Annex IV on the Assessment of the Quality of the Marine Environment and Annex V on Protection and Conservation of the Ecosystems and Biological Diversity of the Maritime Area;

- various bodies established under the International Council for the Exploration of the Sea (ICES), in particular the Arctic Fisheries Working Group;

- bodies established under the North Pacific Marine Science Organisation (PICES) ${ }^{58}$ and

- the International Arctic Science Committee (IASC).

e. International instruments

\section{Introduction}

As a point of departure, it should be noted that all the global legally binding and non-legally binding instruments related to fisheries conservation and management are also applicable to the Arctic marine area. The most important ones are:

- the LOS Convention;

- the Fish Stocks Agreement;

- the FAO Compliance Agreement; $;^{59}$

57 Convention for the Protection of the Marine Environment of the North-East Atlantic, Paris, 22 September 1992. In force 25 March 1998. Annex V, Sintra, 23 September 1998. In force 30 August 2000; See also http://www.ospar.org.

${ }^{58}$ For information see http://www.pices.int.

59 Agreement to Promote Compliance with International Conservation and Management Measures by Fishing Vessels on the High Seas, Rome, 24 November 1993. In force 24 April 2003, 33 ILM 969 (1994). See also http://www.fao.org/legal. 
- the FAO Code of Conduct for Responsible Fisheries ${ }^{60}$ and its Technical Guidelines, international plans of action (IPOAs) - for instance the IPOAIUU $^{61}$ - and the Model Scheme on PSM; ${ }^{62}$ and

- UNGA Resolutions, among other things on driftnets and destructive fishing practices. ${ }^{63}$

The subsections below will address in some more detail the LOS Convention, the Fish Stocks Agreement, constitutive instruments of RFMOs and Arrangements and their conservation and management measures and Arctic Council instruments. Finally, for the sake of completeness reference should be made here to the OSPAR Convention and the Treaty of Spitsbergen.

\section{f. LOS Convention}

In addition to acknowledging the sovereignty, sovereign rights and jurisdiction of coastal states over all or certain living resources within their maritime zones and the freedom of fishing of all states in the high seas, ${ }^{64}$ the LOS Convention lays down several basic obligations which restrict these entitlements. These are: ${ }^{65}$

1. avoiding over-exploitation of target species by means of

a. determining the TAC, inter alia, by taking account of

i. dependent species (predator-prey relationships) and by-catch of associated species;

ii. generally recommended minimum standards;

${ }^{60}$ Adopted by the Twenty-eight Session of the FAO Conference, Rome, 31 October 1995, available from http://www.fao.org/fi (accessed 26 February 2009).

${ }^{61}$ International Plan of Action to Prevent, Deter and Eliminate Illegal, Unreported and Unregulated Fishing. Adopted by consensus by FAO's Committee on Fisheries on 2 March 2001 and endorsed by the FAO Council on 23 June 2001 available at http://www.fao.org/fi (accessed 26 February 2009).

${ }^{62}$ Model Scheme on Port State Measures to Combat Illegal, Unreported and Unregulated Fishing endorsed by COFI at its Twenty-Sixth Session in March 2005. Reference should in this context also be made to the FAO Technical Consultation to Draft a Legally-Binding Instrument on Port State Measures to Prevent, Deter and Eliminate Illegal, Unreported and Unregulated Fishing, which commenced in June 2008 and may conclude its work in 2009. This future Agreement will make the Model Scheme redundant.

${ }^{63}$ See inter alia UNGA Resolution No. 61/105, of 8 December 2006, 'Sustainable fisheries, including through the 1995 Agreement for the Implementation of the Provisions of the United Nations Convention on the Law of the Sea of 10 December 1982 relating to the Conservation and Management of Straddling Fish Stocks and Highly Migratory Fish Stocks, and related instruments', in particular paras 59 and $80-86$.

${ }^{64}$ See the Introduction to the background papers.

${ }^{65}$ See, among other things, Arts 61-68, 116-120 and 194(5) of the LOS Convention. 
b. using the best available scientific research available, where appropriate by cooperating within relevant international organisations;

2. avoiding or limiting by-catch of non-target species;

3. avoiding or limiting other impacts of fisheries on the marine ecosystem, for instance fragile ecosystems as well as the habitat of depleted, threatened or endangered species;

4. striving for the objective of maximum sustainable yield (MSY), except for marine mammals, sedentary species and species whose range of distribution does not extend seaward of the territorial sea;

5. cooperating in relation to transboundary stocks and discrete high seas stocks. The following different categories of transboundary stocks can be distinguished

a. shared stocks: between the EEZs of two or more coastal states;

b. straddling stocks: occurring within the EEZs of one or more coastal states and the high seas;

c. highly migratory stocks: the species listed on Annex I to the LOS Convention (in particular tuna and tuna-like species); and

d. anadromous (e.g. salmon) \& catadromous (e.g. eel) stocks.

\section{g. Fish Stocks Agreement}

As explained in the Introduction to the background papers, the Fish Stocks Agreement is an Implementation Agreement of the LOS Convention. It does not deal with all of the LOS Convention's categories of stocks, but exclusively with straddling fish stocks and highly migratory fish stocks. Its objective is "to ensure the long-term conservation and sustainable use of straddling fish stocks and highly migratory fish stocks". ${ }^{66}$ Its scope of application encompasses not only areas beyond national jurisdiction but also areas within national jurisdiction. ${ }^{67}$

While the Fish Stock Agreement does not alter the basic jurisdictional framework of the LOS Convention, ${ }^{68}$ the basic provisions of the LOS Convention are broadened, strengthened and specified in more detail in the Fish Stocks Agreement in relation to straddling and highly migratory fish stocks. This includes the requirements to apply a precautionary approach and an ecosystem approach to fisheries, ${ }^{69}$ to protect biodiversity in the marine environment, the concept of compatibility, a variety of specific obligations for flag states, high seas enforcement powers for non-flag states and rights and obligations for port states.

${ }^{66}$ Art. 2 of the Fish Stocks Agreement.

67 Art. 3 of the Fish Stocks Agreement.

${ }^{68}$ Art. 4 of the Fish Stocks Agreement stipulates that the Agreement "shall be interpreted and applied in the context of and in a manner consistent with the [LOS] Convention".

${ }^{69}$ Even though this terminology is not explicitly used. 
In contrast with the LOS Convention, the Fish Stocks Agreement regards RFMOs and Arrangements as the preferred vehicles for fisheries regulation at the regional level. It imposes obligations on States Parties to the Fish Stocks Agreement to cooperate through appropriate existing RFMOs and Arrangements. Of crucial importance in that regard is Article 8(4), which stipulates that access to fisheries is limited to cooperating states. New is also the right in Article 8(3) of states with a 'real interest' to become members of RFMOs or participants in Arrangements. Arguably, the duty to cooperate with the relevant RFMO or Arrangement laid down in Article 8(3) is already part of customary international law and thereby entitles the relevant members or participants to take measures against (non-cooperating) non-members and non-participants that would otherwise be in violation of international law, for instance trade-related measures. ${ }^{70}$ The practice of RFMOs on trade-related measures has at any rate not been challenged by means of the establishment of a dispute settlement procedure under the World Trade Organisation.

RFMOs and Arrangements are to be established where these do not exist. ${ }^{71}$ Moreover, as a consequence of in particular bottom-fisheries targeting deepsea fish species - which are often discrete high seas fish stocks - there is broad support in the international community to ensure that all areas beyond national jurisdiction are covered by RFMOs or Arrangements. Such coverage would ensure that all target fisheries fall within the mandate of an RFMO or Arrangement. Moreover, these RFMOs or Arrangements need to have modern ecosystem-based fisheries management mandates that also allow them to address fisheries impacts on non-target species (including on benthic habitats). ${ }^{72}$ These developments have among other things led to the 'filling' of gaps in such coverage in the Southern Indian Ocean and the establishment of negotiation processes to fill gaps in the Southern Pacific and the Northern or Northwest Pacific. ${ }^{73}$ Within the United States, these developments have led to the adoption of Senate joint resolution (SJ Res.) No. 17 of 2007..$^{4}$

The Fish Stocks Agreement does not establish a regulatory body but provides for the convening of a review conference in its Article 36. While this was likely to have been envisaged as a one-off event, the Review Conference

\footnotetext{
${ }^{70}$ Cf. See UNGA Resolution No. 61/105, note 63 supra, at para. 46.

${ }^{71}$ Cf. Art. 8(5) of the Fish Stocks Agreement.

${ }^{72}$ See UNGA Resolution No. 61/105, note 63 supra, at para. 82.

${ }^{73}$ See note 55 supra. See also the overview of gaps in K.M. Gjerde, "Regulatory and Governance Gaps in the International Regime for the Conservation and Sustainable Use of Marine Biodiversity in Areas beyond National Jurisdiction" (IUCN Marine Law and Policy Paper No. 1: 2008; available at http://www.iucn.org (accessed 26 February 2009), at pp. 5-6.

${ }^{74}$ See section 6.
} 
on the Fish Stocks Agreement that convened in May $2006^{75}$ was not formally closed and will resume in 2010. This may transform the review conference into a permanent or at least regularly recurring forum in which the implementation of the Fish Stocks Agreement and RFMOs and Arrangements can be discussed and where recommendations can be made to improve such implementation.

The non-applicability of the Fish Stocks Agreement to stocks other than straddling and highly migratory fish stocks came in particular to the fore as a consequence of bottom-fisheries targeting deep-sea fish species - which are often discrete high seas fish stocks. It has been proposed that a legally binding instrument is needed to address this gap. ${ }^{76}$ So far, however, there is not much more than the following operative paragraph in a UNGA Resolution, which reads:

Calls upon all States, directly or through regional fisheries management organizations and arrangements, to apply widely, in accordance with international law and the Code, [footnote omitted] the precautionary approach and an ecosystem approach to the conservation, management and exploitation of fish stocks, including straddling fish stocks, highly migratory fish stocks and discrete high seas fish stocks, and also calls upon States parties to the Agreement to implement fully the provisions of article 6 of the Agreement as a matter of priority. ${ }^{77}$

While this paragraph applies in principle to all fish stocks, its purpose seems mainly aimed to singling out discrete high seas fish stocks. In the Arctic context, however, new fishing opportunities are also likely to relate to shared and anadromous fish stocks. The non-applicability of the Fish Stocks Agreement to these fish stocks would mean that only the relatively general obligations contained in the LOS Convention apply.

\section{h. Constitutive Instruments of RFMOs and Arrangements and their Conservation and Management Measures}

This subsection deals with multilateral fisheries conservation and management. An important first distinction is between multilateral fisheries conservation and management that applies explicitly to the Arctic marine area and that which applies implicitly or less explicitly to the Arctic marine area.

\footnotetext{
${ }^{75}$ See Report of the Review Conference on the Fish Stocks Agreement (UN Doc. A/CONF.210/ 2006/15, of 5 July 2006), at p. 39, para 43(d).

${ }^{76}$ See, inter alia, E.J. Molenaar, "Current Legal and Institutional Issues Relating to the Conservation and Management of High Seas Deep Sea Fisheries", in 'Report and documentation of the Expert Consultation on Deep-Sea Fisheries in the High Seas, Bangkok, Thailand, 21-23 November 2006' (FAO Fisheries Report No. 838; 2007): 113-139, at 129-133.

${ }^{77}$ UNGA Resolution No. 61/105, note 63 supra, at para. 5.
} 
The latter category consists of two examples, namely the WCPFC and the ICCAT. The WCPFC Convention Area "comprises all waters of the Pacific Ocean", but does not have an agreed northern boundary. ${ }^{78}$ That means that the Bering Sea would come within the scope of the WCPFC, provided tuna or tuna-like species within its mandate occur therein. The ICCAT Convention Area consists of the "waters of the Atlantic Ocean, including the adjacent Seas." ${ }^{\prime \prime}$ It is very likely that its negotiators had the Mediterranean and Caribbean Seas, but not the Arctic Sea, in mind when agreeing on this phrase. Nevertheless, as there is no agreed definition for, or northern limit of, the Atlantic Ocean, ICCAT may in principle have competence within the entire FAO Statistical Area No. $18{ }^{80}$ with regard to the tuna and tuna-like species within its competence. It should be noted, however, that the occurrence of tuna or tuna like species is currently and in the near future likely to be confined to the most southern parts of the Arctic marine area. Occurrence in the Arctic Ocean will be even further ahead in the future.

The regulatory areas of all the other RFMOs and Arrangements listed in section $d$ apply explicitly to part of the Arctic marine area. Moreover, NEAFC does not exercise its full competence with regard to the Loophole, which is governed by the Norway-Russian Federation Fisheries Commission and the Loophole Agreement and Protocols. Whereas the main focus of the latter is on demersal species, the main focus of NEAFC is on pelagic and deep-sea fisheries. It may of course be possible that NEAFC will actually also exercise species competence in the Loophole in the future, for instance if a fishery for one or more pelagic species in the Loophole would become commercially viable. ${ }^{81}$

As regards the NASCO Convention, pursuant to Article 1(1) it "applies to the salmon stocks which migrate beyond areas of fisheries jurisdiction of coastal states of the Atlantic Ocean north of $36^{\circ} \mathrm{N}$ latitude throughout their migratory range." In the absence of an agreed definition for, or northern limit of, the Atlantic Ocean, it seems possible for NASCO to exercise competence over salmon in the entire FAO Statistical Area No. $18 .^{82}$

\footnotetext{
${ }_{78}^{78}$ Art. 3(1).

${ }^{79}$ Art. I.

${ }^{80}$ See note 13 supra and accompanying text.

${ }^{81}$ It should be noted, however, that the provisions in the NEAFC Scheme of Control and Enforcement (in force 1 May 2008) on 'Port State Control of Foreign Fishing Vessels' are made applicable to the NEAFC Convention Area by Art. 20 and thereby also the area covered by the Norway-Russian Federation Fisheries Commission and the Loophole Agreement and Protocols.

${ }^{82}$ This may nevertheless require adjustment of the spatial scope and composition of NASCO Commissions.
} 
As regards the Bering Sea, the overview above indicates that it is explicitly covered by at least four multilateral regimes in addition to the WCPFC Convention. While these regimes all focus on a single species or a single group of species (anadromous), it should be noted that the CBS Convention can also be applied to "living marine resources other than Pollock." 83

The content of these constitutive instruments varies considerably and in the context of this article it is not possible - and arguably also not necessary - to examine it in depth. Among other things, the older instruments are relatively concise and simple and the newer ones much more extensive and complex, largely as a consequence of the progressive development of international fisheries law. The substantive standards of these RFMOs and Arrangements are in most cases laid down in conservation and management measures that are adopted or revised during periodic meetings. ${ }^{84}$

As a consequence of the growing crisis in marine capture fisheries globally, both as regards over-exploitation of target species and the impacts on non-target species, processes have been set in motion to upgrade the constitutive instruments of these RFMOs and Arrangements to enable them to carry out the objectives of the Fish Stocks Agreement in light of the functions of RFMOs pursuant to Article 10 of the Fish Stocks Agreement. These processes are, to put it differently, aimed at making them 'compatible' with the Fish Stocks Agreement and other modern international instruments. The upgrades are among other things aimed at replacing older mandates with EAF mandates. In addition, several RFMOs have agreed to their performance being assessed. ${ }^{85}$

\section{i. Arctic Council Instruments}

The Arctic Council has so far not focused on the conservation and management of target species and can also not be equated with an RFMO or Arrangement. ${ }^{86}$ However, especially CAFF has been and still is engaged in

${ }^{83}$ Art. II(4) of the CBS Convention.

${ }^{84}$ In the case of the Norway-Russian Federation Fisheries Commission these are to a large extent laid down in the so-called 'Grey Zone Agreement' (original title: Avtale mellom Norge og Sovjetunionen om en midlertidig praktisk ordning for fisket $i$ et tilstøtende område $i$ Barentshavet med tilhørende protokoll og erkloring, translated to "Agreement between Norway and the Soviet Union on a temporary and practical arrangement for the fishery in an adjacent area of the Barents Sea"; available in the Norwegian treaty Series; Overenskomster 1978 p. 436). This is a temporary agreement first adopted in 1978 and renewed annually since then.

${ }^{85}$ The first performance assessment of an RFMO related to NEAFC.

${ }^{86}$ Note that most Members of the Commission for the Conservation of Antarctic Marine Living Resources (CCAMLR) - which is part of the Antarctic Treaty system - do not regard 
various important monitoring and assessment activities, such as Circumpolar Biodiversity Monitoring Program and the Arctic Biodiversity Assessment. ${ }^{87}$ These would seem very useful for international fisheries conservation and management.

\section{National Regulation}

Within the context of this article it is not possible to give an overview of national regulation by Arctic states on the conservation and management of target species and the regulation of the impacts of fishing on non-target species within the Arctic marine area. In some parts of the Arctic marine area, for instance the North Atlantic, national regulation is expected to be extensive and relate to all or most of the relevant capacities in which states can exercise jurisdiction, namely as flag, coastal, port and market states and with regard to their natural and legal persons.

For other parts of the Arctic marine area, however, the presence of ice for most of the year has so far rendered national fisheries regulation for those areas unnecessary. But as diminishing ice-coverage will attract fishing vessels looking for possible new fishing opportunities, Arctic states will be required to develop national regulation in order to discharge their obligations under international law, including those under the LOS Convention and the Fish Stocks Agreement. The United States is currently engaged in this process with regard to fishing in the maritime zones off Alaska north of the Bering Strait. In the United States, competence over fisheries is shared by the individual states (in this case Alaska) within $3 \mathrm{~nm}$ from shore and the federal government in the remainder of the United States maritime zones. The North Pacific Fishery Management Council (NPFMC) plays a key role in federal regulation with regard to the maritime zones of the United States in the North Pacific. The NPFMC has adopted various fishery management plans (FMPs) that apply as far north as the Bering Strait and its King and Tanner Crab and Scallop FMPs also apply to that part of the Chukchi Sea that lies between the Bering Strait and Point Hope. In June 2007, the NPFMC

CCAMLR as an RFMO. However, most take the view that CCAMLR is 'something more than an RFMO'.

${ }^{87}$ For information see http://www.arcticportal.org/en/caff. See also T. Koivurova and D.L. VanderZwaag, "The Arctic Council at 10 Years: Retrospects and Prospects" University of British Columbia Law Review 40 (2007): 121-194, at 147-149. 
closed the Northern Bering Sea to bottom trawling and directed a research plan to be developed for that area. ${ }^{88}$

Since October 2006, the NPFMC has also specifically focused its attention on Arctic fishery management. This eventually culminated in the adoption of the Arctic FMP on 5 February 2009. ${ }^{89}$ The Arctic FMP entails, inter alia, to "close the Arctic to commercial fishing so that unregulated fishing does not occur and until information improves so that fishing can be conducted sustainably and with due concern to other ecosystem components".$^{90}$

In light of these developments in the United States, it would be important to know if other states - both Arctic and non-Arctic - have policies on Arctic fisheries as such or on Arctic fisheries in the context of climate change. The January 2009 Arctic Region Policy of the United States ${ }^{91}$ contains a few paragraphs on fisheries but not a separate section..$^{92}$ Conversely, Section 3.2 of the European Commission's Arctic Communication ${ }^{93}$ is specifically devoted to 'Fisheries' and is among other things supportive of the approach pursued by the United States by means of its NPFMC. ${ }^{94}$ Finally, reference can be made to the Canadian 'New Emerging Fisheries Policy' that was adopted in 2001. ${ }^{95}$ While nothing in its text indicates that it was specifically developed for Arctic fisheries in the context of climate change, it may nevertheless be useful.

As some of the fish stocks in the EEZ off Alaska are likely to be transboundary, reference should be made to the United States Senate joint Resolution (SJ Res.) No. 17 of 2007, "directing the United States to initiate international discussions and take necessary steps with other Nations to negotiate an agreement for managing migratory and transboundary fish stocks in the

${ }^{88}$ News \& Notes, June 2007, at p. 2 available at http://www.fakr.noaa.gov/npfmc (accessed 26 February 2009).

${ }^{89}$ Council Motion of 5 February 2009 'Arctic Fishery Management Plan'. The United States Secretary of Commerce still has to act on this motion.

90 Arctic FMP EA/RIR/IRFA Public Review Draft, note 16 supra, at p. iii. By means of its Motion of 5 February 2009, note 89 supra, the Council opted for Alternative 2, Option 3.

${ }^{91}$ National Security Presidential Directive/NSPD-66 \& Homeland Security Presidential Directive/HSPD-25, of 9 January 2009. In effect same day; text available athttp://www.whitehouse.gov (press release of 12 January 2009).

${ }_{92}$ See sections $\mathrm{III}(\mathrm{H})(4)$ and $(6)(\mathrm{b})$ and (c).

${ }^{93}$ COM (2008) 763, of 20 November 2008, 'Communication from the Commission to the European Parliament and the Council on The European Union and the Arctic Region'.

${ }^{94}$ On p. 8 it is observed "Until a conservation and management regime is in place for the areas not yet covered by such a regime, no new fisheries should commence". See also the discussion in subsection 7.d.

${ }_{95}$ Available at http://www.dfo-mpo.gc.ca/communic/fish_man/nefp_e.htm (accessed 7 August 2008). 
Arctic Ocean". ${ }^{96}$ The United States also brought SJ Res. No. 17 of 2007 to the attention of SAOs during their meeting in November 2007. During the discussion that followed there was "strong support for building on and considering this issue within the context of existing mechanisms." seem to indicate that a considerable majority of the Arctic states do not want the Arctic Council to become directly involved in fisheries management and conservation.

Finally, mention should be made of fisheries conservation and management in the fisheries protection zone established by Norway off Svalbard. This fisheries conservation and management can be categorised as unilateral, even though Norway allocates fishing opportunities for certain species to some contracting parties to the Treaty of Spitsbergen.

\section{Gaps in the International Legal and Policy Framework and National Regulation and Options for Addressing Them}

\section{a. Gaps}

Even though all the global intergovernmental organisations, bodies and legally binding and non-legally binding instruments related to fisheries conservation and management are also applicable to the Arctic marine area, a large part of the Arctic marine area is not covered by an RFMO or Arrangement with competence over target species other than tuna and tuna-like species and anadromous species. ${ }^{98}$ The Arctic Council has so far not focused on the conservation and management of target species, lacks an express mandate for conserving or managing Arctic fisheries and also seems unwilling to become directly involved in fisheries management and conservation. The Arctic Council can at any rate not be equated with a RFMO or Arrangement.

There are several bilateral arrangements between the relevant Arctic Ocean coastal states on the conservation and management of shared fish stocks within the Arctic marine area. However, some are missing. This would seem to relate to Canada - United States (Beaufort Sea), Canada - Greenland and Russian Federation - United States (Chukchi Sea).

\footnotetext{
${ }^{96}$ Passed by the Senate on 4 October 2007. The House of Representatives voted in favor of SJ Res. No. 17 in May 2008 and President Bush signed it on 4 June 2008.

${ }^{97}$ Final Report of the Meeting of Senior Arctic Officials, 28-29 November 2007, Narvik, Norway available at http://www.arctic-council.org (accessed 26 February 2009), at12.

${ }_{98}$ This conclusion assumes that the Bering Sea would come within the scope of the WCPFC, and that ICCAT and NASCO may in principle have competence within the entire FAO Statistical Area No. 18.
} 
In some parts of the Arctic marine area, the presence of ice for most of the year has up until now rendered national fisheries regulation unnecessary. However, as diminishing ice-coverage will attract fishing vessels looking for possible new fishing opportunities, Arctic states will have to develop national regulation in order to discharge their obligations under international law.

Another gap relates to science and data. The complexity of the functioning of Arctic marine ecosystems as well as the limitations and shortcomings of science were noted in the ACIA. ${ }^{99}$ It is most likely that a lot of data required for pursuing an EAF is presently also not available. Fortunately, these aspects played a crucial role in the development of the Arctic FMP within the NPFMC.

\section{b. Options}

\section{General}

This subsection contains various options for adjusting the current international legal framework relating to fisheries in the Arctic marine area in case such adjustments are regarded as necessary in view of current or future threats of fisheries to the marine environment and marine biodiversity in the Arctic marine area. An assessment of the need for such adjustments should start with conducting basic fisheries research as well the development of future scenarios about areas, dates, species, fishing techniques for which new fishing opportunities are likely to arise and potential impacts for non-target species. It may for instance reveal that new fishing opportunities in the Pacific side of the Arctic Ocean will be mainly located in the maritime zones of coastal states for a considerable time, whereas fishing opportunities in Atlantic side may much sooner also encompass the high seas that were not fished before. Such an assessment could be carried out within the framework of the Arctic Council (e.g. through (CAFF)) or outside, for instance by ICES or IASC.

In view of the discussion at the meeting of SAOs in November 2007, there is currently considerable opposition within the membership of the Arctic Council against it becoming actively involved in fisheries management and conservation. This opposition is likely to mean that the Arctic Council may not be used as a forum for discussing the options identified in this subsection, let alone be used as a forum for negotiating a legally binding or non-legally binding instrument on Arctic fisheries conservation and management.

In addition to ensuring the availability of relevant scientific data, inter alia by developing the scenarios mentioned above, the following options can be identified:

\footnotetext{
${ }^{99}$ See section 3 .
} 
- individual action by Arctic Ocean coastal states and other states in their capacities as flag, coastal, port and market states and with regard to their natural and legal persons;

- bilateral or subregional arrangements between the relevant Arctic Ocean coastal states on the conservation and management of shared fish stocks;

- a declaration or statement by which the main relevant general principles of the Fish Stocks Agreement, the recent UNGA Resolutions in relation to vulnerable marine ecosystems and destructive fishing practices and relevant conservation and management measures drawn from RFMOs ${ }^{100}$ are made applicable to new and existing fisheries in the Arctic marine area. In particular, this declaration could stipulate that there shall be no new fisheries until adequate assessments of their potential impacts on target and non-target species and livelihoods of indigenous peoples are carried out;

- mechanisms or procedures similar to an environmental impact assessment (EIA) and/or a strategic impact assessment (SEA) for new fisheries in the Arctic marine area; and

- one or more state-of-the-art RFMOs or Arrangements, whether self-standing or as part of a legally binding framework instrument for the Arctic and possibly in conjunction with adjustments in the competence of existing RFMOs or Arrangements, in particular in geographical terms.

\section{Declaration on new and existing fisheries in the Arctic Ocean}

As one of the options referred to in the previous subsection is a declaration or statement, reference should be made to recent initiatives undertaken by the United States pursuant to United States SJ Res. No. 17 of 2007..$^{101}$ These include informal bilateral consultations with a number of relevant players, including the other Arctic Ocean coastal states, on their willingness to support a process which would culminate in a general statement or declaration on present and future Arctic fisheries. At the next Session of the Committee on Fisheries (COFI) of the United Nations Food and Agriculture Organisation (FAO) in March 2009, the United States plans to convene a side-event to discuss this process. The United States may approach another Arctic Ocean coastal state - for instance Norway - to co-sponsor this initiative. At this side-event, the United States may offer to host a high-level conference on Arctic fisheries in 2010 during which such a general statement or declaration

\footnotetext{
100 E.g. CCAMLR Conservation Measures 21-01 (2008) 'Notification that Members are considering initiating a new fishery' and 21-02 (2008) 'Exploratory fisheries'.

${ }^{101}$ See note 96 supra and accompanying text.
} 
could be adopted. ${ }^{102}$ As noted above, the European Commission's Arctic Communication would seem to be supportive of such an initiative. ${ }^{103}$

\section{Adjusting the Spatial Scope of the NEAFC Convention}

One of the options listed in the subsection is the development of one or more state-of-the-art RFMOs or Arrangements for species other than tuna and tuna-like species and anadromous species. That bullet also mentions that this may require "adjustments in the competence of existing RFMOs or Arrangements, in particular in geographical terms". An obvious candidate for a spatial adjustment is NEAFC. The five existing members of NEAFC are the European Community (EC), Denmark on behalf of the Faroe Islands and Greenland, Iceland, Norway and the Russian Federation. Unlike the OSPAR Convention, the NEAFC Convention does not explicitly mention the option of amending its spatial scope. On the other hand, there is also nothing in Article 19 or elsewhere in the NEAFC Convention that would preclude spatial adjustments as such.

It should be noted that the NEAFC Convention's eastern boundary and the western boundary north of Greenland ${ }^{104}$ do not coincide with the two relevant boundaries of FAO Statistical Area No. 18, entitled 'Arctic Sea'. While the spatial scope of the NEAFC Convention is identical to the spatial scope of its 1959 predecessor, ${ }^{105}$ the two relevant boundaries of FAO Statistical Area No. 18 already existed in 1970 and have not changed since then. ${ }^{106}$ The spatial scope of the OSPAR Convention and its two predecessors - the Oslo

${ }^{102}$ Information based on conversations between E.J. Molenaar and a governmental official of the United States in December 2008, January and March 2009. The United States Arctic Region Policy, note 91 supra, does not refer to the possibility of such a process in the relevant implementation section (section $\operatorname{III}(\mathrm{H})(6))$.

${ }_{103}$ See note 94 supra.

104 Note, however, that the NEAFC Convention Area and the OSPAR Maritime Area do not appear to encompass the waters north of Greenland between $44^{\circ}$ west longitude and $42^{\circ}$ west longitude extending to the North Pole. While Art. 1(a)(1) of the NEAFC Convention and Art. 1(a)(i) of the OSPAR Convention use the phrase "Atlantic and Arctic Oceans", the term 'Arctic' does not appear in Art. 1(a)(2) of the NEAFC Convention or Art. 1(a)(2) of the OSPAR Convention. While it may sometimes be difficult to point out where the Arctic Ocean begins and the Atlantic Ocean ends, the waters north of Greenland would seem undoubtedly part of the Arctic Ocean. In the fall of 2008, the Secretary of NEAFC approached the Members of NEAFC to obtain their view on this issue.

105 The North-East Atlantic Fisheries Convention (London, 24 January 1959). In force 27 June 1963; 486 UNTS 157. See also http://www.neafc.org.

${ }^{106}$ See the historical FAO statistical charts at ftp.fao.org/fi/maps/Default.htm. 
Convention ${ }^{107}$ and the Paris Convention ${ }^{108}$ - is also identical to that of the NEAFC Convention (and its 1959 predecessor). Interestingly, the ICES Convention stipulates that the spatial mandate of is "the Atlantic Ocean and its adjacent seas", but the northern boundaries of the 'ICES Areas' are identical to those of FAO Statistical Area No. 18.

The rationale for the northern boundaries of the predecessor to the NEAFC Convention is not evident. Perhaps they simply demarcated the most northerly range of distribution that commercially significant fish stocks could possibly have in the most optimistic scenario and then just a bit further north to be on the safe side. It should also be noted that until recently the exact location of the northern boundaries did not have practical relevance for NEAFC.

While spatial adjustments are thus possible, it is submitted that only relatively small geographical adjustments - expansions as well as shrinkages - do not seem problematic. Such adjustments could for instance follow maritime boundaries or ecosystem boundaries between different hydrographic regimes, submarine topography and distributional ranges of certain target species or other species. ${ }^{109} \mathrm{~A}$ well-known example of an international regulatory regime whose spatial scope was mainly determined by ecosystem boundaries is the CCAMLR Convention by which the Commission for the Conservation of Antarctic Marine Living Resources (CCAMLR) was established. ${ }^{110}$ Even in that case, however, the approximation of the Antarctic Convergence agreed to during the negotiation of the CCAMLR Convention, took account of political considerations, thereby causing a small diversion from pre-existing FAO Statistical Areas. ${ }^{111}$

107 Convention for the Prevention of Marine Pollution by Dumping from Ships and Aircraft, Oslo, 15 February 1972. In force 7 April 1974, 932 UNTS 4, as amended. See Art. 2.

${ }^{108}$ Convention for the Prevention of Marine Pollution from Land-Based Sources, Paris, 4 June 1974. In force 6 May 1978, 1546 UNTS 119, as amended. See Art. 2.

109 See L.M. Alexander, "Large Marine Ecosystems as Global Management Units", in K. Sherman and L.M. Alexander (eds.): Biomass Yields and Geography of Large Marine Ecosystems, (Boulder, Westfield Press, 1989): 339-344, at 339.

${ }^{110}$ It is of course acknowledged that regimes for enclosed or semi-enclosed seas are also mainly or exclusively determined by ecosystem boundaries.

111 J.N. Barnes, "The Emerging Convention on the Conservation of Antarctic Marine Living Resources: An Attempt to Meet the New Realities of Resource Exploitation in the Southern Ocean", in J.I. Charney (ed.) The New Nationalism and the Use of Common Spaces (Allanheld, Osmun Publishers: 1982): 239-286, at 262 observes that at the insistence of Argentina, the boundary was drawn further away from Argentine territory in order to exclude the Drake Passage (FAO statistical charts were later modified accordingly (see the historical FAO statistical charts at ftp.fao.org/fi/maps/Default.htm). Cf. also F.M. Auburn, Antarctic Law and Politics (Indiana University Press: 1982), at 218 and 292. 
For the purpose of adjusting the spatial scope of the NEAFC Convention, account could perhaps be taken of the large marine ecosystems (LMEs) of the Arctic marine area developed by the PAME (Protection of the Marine Environment) working group of the Arctic Council. ${ }^{112}$ A quick comparison of these LMEs with the current spatial scope of the NEAFC Convention might suggest that, for instance, the latter's spatial scope could be expanded by including all of LME no. 20, entitled 'Barents Sea' and perhaps even LME no. 58, entitled 'Kara Sea' as well. Another option would be to restrict the spatial scope of the NEAFC Convention by excluding the spatial scope of LME no. 64, entitled 'Arctic Ocean'. The spatial scope of FAO Statistical Area No. 18 , could then be adjusted accordingly. ${ }^{113}$

A word of caution is warranted here, however. While the Arctic LMEs defined by PAME have taken account of 'trophic relationships', ${ }^{114}$ this is quite different from a criterion such as 'usefulness for conservation and management of target species'. And even if the latter criterion were in fact used, the negotiations on the CCAMLR Convention illustrate that political considerations can override science-based criteria. Another political consideration would nevertheless attribute great weight to the LMEs defined by PAME. This would be the wish to pursue integrated, cross-sectoral ecosystem based ocean governance (see subsection below).

By contrast, large expansions by which the NEAFC Convention Area would comprise the entire Arctic Ocean - as suggested in the European Commission's Arctic Communication ${ }^{115}$ - appear much more problematic. This is not so much caused by the interests of the 'new' coastal states, namely Canada and the United States. In fact, Canada is not really a 'new' coastal state as it currently already has the status of Cooperating Non-Contracting Party (NCP) with NEAFC. In light of this status, Canada may even apply for full membership in the future. NEAFC's existing spatial competence in the Atlantic sector of the Arctic as well as potential adjustments of this spatial competence do not appear to have played a role in Canada's decision to apply for NCP status. ${ }^{116}$ This does not exclude, however, that such consid-

112 These can be found on http://www.arcticportal.org/en/pame.

113 The historical FAO statistical charts referred to in note 111 above indicate that this is a common practice.

114 PAME Working Group Meeting Report No. I-2006, at 11.

115 On p. 8 it is observed that "In principle, extending the mandate of existing management organisations such as NEAFC is preferable to creating new ones."

116 Email correspondence between E.J. Molenaar and L. Ridgeway, Director General, International Policy and Integration, Fisheries and Oceans Canada, November 2008. 
erations could not play a role in the future. ${ }^{117}$ In case Canada would indeed apply for full membership, this would at any rate indicate its willingness to accept the substance of the NEAFC Convention as modified by the 2004 and 2006 amendments. ${ }^{118}$ It is less clear if the United States would have significant problems with the substance of the amended NEAFC Convention.

Perhaps more important, however, is whether or not Canada and the United States have fundamental objections to NEAFC's practices on the establishment and allocation of the total allowable catch (TAC) for straddling fish stocks, for the reason that these clearly give preferential treatment to coastal states. The initiative lies here with the coastal states, who first agree on a coastal state TAC while taking account of the scientific advice provided by ICES. ${ }^{119}$ However, as the ICES advice relates to the entire stock, the coastal states effectively determine the high seas TAC as well. The coastal states also allocate the coastal state TAC between them without specifying which part of each coastal state's allocation should be caught within or beyond areas under national jurisdiction. ${ }^{120}$ NEAFC is then charged with determining and allocating the high seas TAC. ${ }^{121}$ Even though room for maneuvering seems limited, it should not be forgotten that there are only five Members of NEAFC and three of these are regarded as coastal states with respect to all three main straddling fish stocks regulated by NEAFC. ${ }^{122}$

While Canada and the United States would, as coastal states, of course benefit from such preferential treatment as well, it is not excluded that they

${ }^{117}$ Of course, once Canada is a member of NEAFC it can participate in decision making on proposals to adjust the spatial scope of the NEAFC Convention. Such decisions require a three-fourths majority (cf. Art. 19).

${ }^{118}$ See note 46 above. It seems that if Canada would insist on acceding to the 'old' version of the NEAFC Convention, this would not attract the necessary majority pursuant to Art. 20(4) of the NEAFC Convention.

119 E.g. the 2007 trilateral coastal state arrangement on Northeast Atlantic mackerel (Agreed record of conclusions of fisheries consultations between Norway, the European Community and the Faroe Islands on the management of mackerel in the North-East Atlantic for 2008, Oslo, 30 October 2007). See also the "Performance Review Panel Report of the North East Atlantic Fisheries Commission, NEAFC” (November 2006), at pp. 14 and 17.

${ }^{120}$ Cf. the 2007 trilateral coastal state arrangement on Northeast Atlantic mackerel, Annex I, at para. 1.

121 With respect to Mackerel, see e.g. the 2008 NEAFC Recommendation on mackerel (Recommendation I: 2008 'Recommendation by the North East Atlantic Fisheries Commission in accordance with Article 5 of the Convention on Future Multilateral Cooperation in North-East Atlantic Fisheries at its Annual Meeting in November 2007 to adopt convention and management measures for mackerel in the NEAFC Convention Area in 2008').

${ }_{122}$ These are blue whiting, herring and mackerel. The Russian Federation is not regarded as a coastal state for blue whiting and mackerel and Iceland is not regarded as a coastal state for mackerel. 
would object to such practices in order to be consistent with their user or non-user interests in other RFMOs and Arrangements. Much more problematic, however, are the user interests of states that are not coastal states with respect to the North-East Atlantic Ocean or the Arctic Ocean, e.g. the other states that currently have the status of NCP with NEAFC (Belize, Cook Islands, Japan and New Zealand) and other states with large distant water fishing fleets, such as China and South Korea. Even though fishing opportunities in the high seas pocket of the central Arctic Ocean are likely to be very minimal in the near future, climate change may alter the Arctic marine area both rapidly and fundamentally in the medium term. Consequently, it cannot be ruled out that fishing opportunities in the high seas of the Arctic Ocean will be substantial in the medium and long term. Not only is the size of the high seas pocket enormous but the fisheries on the nose and tail of the Grand Banks in the Northwest Atlantic also aptly illustrate that just a small area of the high seas may be sufficient.

\section{Integrated, Cross-sectoral Ecosystem-based Ocean Management}

So far, this article has approached Arctic fisheries conservation and management exclusively by means of a sectoral perspective. The inherent limitations of sectoral approaches to ocean management are increasingly wider recognised and have led to various non-legally binding commitments to pursue ecosystem-based ocean management at the global level. ${ }^{123}$ While there is currently no universally accepted definition for the term integrated, crosssectoral ecosystem-based ocean management', ${ }^{124}$ it is nevertheless widely accepted that the different words included in the term indicate a holistic approach which takes due account of spatial dimensions, processes and relationships within ecosystems. ${ }^{125}$ It is also submitted that integrated, crosssectoral ecosystem-based ocean management operates at a higher hierarchical level than sectoral ecosystem-based management, for instance EAF.

${ }^{123}$ E.g. paras 30(d) and 32(c) of the JPOI (Plan of Implementation of the World Summit on Sustainable Development, Johannesburg, 4 September 2002; available at http://www.unep .org (accessed 26 February 2009) and UNGA Resolution No. 61/222, 'Oceans and the law of the sea', of 20 December 2006, at para. 119.

124 Cf. the 'Report on the work of the United Nations Open-ended Informal Consultative Process on Oceans and the Law of the Sea at its seventh meeting' (UN doc. A/61/156, of 17 July 2006), which notes this at para. 6 and subsequently lists various elements relating to ecosystem approaches and oceans.

${ }^{125}$ See the elements referred to in note 124 supra. 
Moreover, sectoral ecosystem-based management can also be pursued in the absence of an overarching integrated approach. ${ }^{126}$

While neither the LOS Convention nor any other global instrument contains a legally binding obligation to pursue integrated, cross-sectoral ecosystem-based ocean management, reference has already been made to relevant commitments above. Support for integrated, cross-sectoral ecosystem-based ocean management also exists within several Arctic states - such as Norway ${ }^{127}$ - and various international bodies that are relevant to the Arctic marine area. For instance, integrated management of resources and ecosystem-based management feature prominently in the program of the Norwegian chairmanship of the Arctic Council (2006-2008) and in the Norwegian, Danish and Swedish common objectives for their Arctic Council chairmanships 2006-2012. ${ }^{128}$ Reference can also be made to the LMEs of the Arctic marine area developed by PAME (see subsection above). Perhaps even more pertinent, however, are the pursuance of the ecosystem approach by the OSPAR Commission $^{129}$ and the large overlap between the spatial competence of the OSPAR Commission, NEAFC and ICES; which is conducive to integrated, cross-sectoral ecosystem-based ocean management. The establishment of cooperative arrangements between NEAFC and OSPAR ${ }^{130}$ and the proposal

${ }^{126}$ Interestingly, the United States Arctic Region Policy, note 91 supra, specifically mentions the objective of pursuing ecosystem-based management in the section on 'Environmental Protection and Conservation of Natural Resources' (section $\operatorname{III}(\mathrm{H})(6)(\mathrm{d})$ ) but not anywhere else.

${ }^{127}$ See the 'Integrated Management of the Marine Environment of the Barents Sea and the Sea Areas off the Lofoten Islands (Management Plan)' (Helhetlig forvaltning av det marine miljø i Barentshavet og havområdene utenfor Lofoten (forvaltningsplan) (St. Meld. Nr. 8 (2005-2006); English version at http://www.regjeringen.no/en/dep/md/Selected-topics/ Svalbard_og_polaromradene.html?id=1324 (accessed 26 February 2009). The plan - which does not extend beyond the maritime zones of Norway - was approved by the Norwegian Parliament in June 2006. See also note 126 supra with regard to the United States.

128 These are available at http://www.arctic-council.org.

${ }^{129}$ See the Statement on the Ecosystem Approach to the Management of Human Activities (Joint Meeting of the Helsinki \& OSPAR Commissions 2003, Record of the Meeting, Annex 5), para. 5.

130 The Draft Memorandum of Understanding (MOU) adopted by the OSPAR Commission is contained in Annex 13 to Summary Record OSPAR 2008, OSPAR 08/24/1-E, at Annex 13. See also para. 7.23(f). The MOU entered into force on 5 September 2008. 
for an OSPAR marine protected area (MPA) situated beyond $200 \mathrm{~nm}$ from the coast ${ }^{131}$ are aimed at testing this conduciveness. ${ }^{132}$

But while most, if not all, states would acknowledge the merits of integrated, cross-sectoral ecosystem-based management of the Arctic marine area, they are likely to have very diverging views on how it should be pursued. For instance, whether it should be pursued at the global or at the regional level or whether it should be pursued by means of legally binding or nonlegally binding instruments. Support for global approaches in this context seems minimal. This can be deduced from the fact that the EU proposal for an Implementing Agreement to the LOS Convention ${ }^{133}$ so far received little support by non-EU member states. Linking a legally binding instrument for the marine Arctic to the LOS Convention ${ }^{134}$ - even if its spatial scope would be limited to areas beyond national jurisdiction (high seas and the Area) - would also not be acceptable to Arctic Ocean coastal states because its negotiation would fall under the UNGA; a forum where the five Arctic Ocean coastal states could potentially be confronted by 180 -odd states with opposing views and interests.

131 "Proposal for an OSPAR area of interest for establishing an MPA on the Mid Atlantic Ridge/Charlie Gibbs Fracture Zone. Presented by WWF, the Netherlands and Portugal" (Doc. OSPAR 08/7/9-E). See also Summary Record OSPAR 2008, OSPAR 08/24/1-E, at paras 7.16-7.24.

${ }_{132}$ See on this issue Koivurova and Molenaar, note 5 supra, at 15-19.

${ }^{133}$ Cf. the Annex to the Statement by Austria, on behalf of the EU, at the 7th Meeting of the ICP (2006) and COM(2007) 575 final, of 10 October 2007, 'An Integrated Maritime Policy for the European Union', at p. 14, where it is noted that the "Commission will propose an Implementing Agreement of UNCLOS on marine biodiversity in areas beyond national jurisdiction and work towards successful conclusion of international negotiations on Marine Protected Areas on the high seas". It should also be noted that the European Commission's Arctic Communication refers to these items as possible policy actions on p. 11. It is not altogether clear, however, why these items with a global scope should be listed in the Arctic Communication. The precise meaning and intention of these items are not clear, but they seem at any rate related to a process at the global level that is intended to have output that applies throughout the globe and not just the Arctic. Or does it imply that the high seas in the Arctic Ocean should be designated as a marine protected area?

${ }^{134}$ This has for instance been suggested by the Executive Director of the European Environment Agency (EEA) J. McGlade, The Arctic Environment - Why Europe should care, speech delivered at the Arctic Frontiers Conference, Tromsø, 23 January 2007, available at http://www.eea.europa.eu/pressroom/speeches/23-01-2007 (accessed 26 February 2009). The actual wording used in this speech is "Polar Ocean protocol". This wording is confusing because it can be interpreted as applying to both the Arctic Ocean and the Southern Ocean. Note that the words "based on UNCLOS" in p. 10 of the European Commission's Arctic Communication indicate that the option of an Implementation Agreement under the LOS Convention is not pursued. 
Regional approaches for pursuing integrated, cross-sectoral ecosystembased ocean management in the marine Arctic are likely to attract more support. ${ }^{135}$ However, the Arctic Ocean coastal states are in view of their Ilulissat Declaration not in favor of a legally binding instrument in case that would amount to "a new comprehensive international legal regime to govern the Arctic Ocean". ${ }^{136}$ Proposals such as those by the European Parliament in its Resolution of 9 October 2008 on Arctic governance ${ }^{137}$ for a treaty inspired by the Antarctic Treaty have the additional hurdle of being too closely associated with the agreement to disagree on the status of sovereignty in Antarctica. ${ }^{138}$ Expanding the spatial scope of the OSPAR Convention to include the entire Arctic Ocean would not strictly speaking be a 'new regime', but it is questionable if Canada, the Russian Federation and the United States would be prepared to accept this entire 'acquis'; namely the OSPAR Convention as well as all the legally binding decisions, non-legally binding recommendations and other agreements adopted by the OSPAR Commission - without significant amendments. An alternative to these legally binding options is to transform the Arctic Council into a mechanism for cooperation and coordination in pursuing integrated, cross-sectoral ecosystem-based ocean management. ${ }^{139}$

${ }^{135}$ For a proposal see T. Koivurova and E.J. Molenaar, "International Governance and Regulation of the Marine Arctic. A Proposal for a Legally Binding Instrument" (WWF, forthcoming in 2009) Also note the idea of a regional oceans management organisation (ROMO) put forward by Rayfuse, note 4 supra, at 215 .

136 See the text accompanying note 36 supra.

137 EP doc. P6_TA-PROV(2008)0474.

138 The United States Arctic Region Policy, note 91 supra, observes that the "geopolitical circumstances of the Arctic region differ sufficiently from those of the Antarctic region such that an "Arctic Treaty" of broad scope - along the lines of the Antarctic Treaty - is not appropriate or necessary" (section III(C)(3)). The European Commission's Arctic Communication has not enthusiastically embraced the suggestion by the European Parliament but, arguably, does not rule out new instruments either (see the terms 'instruments' and 'frameworks' on 10 and 11).

139 See for instance D. McRae, "Rethinking the Arctic: A New Agenda for Canada and the United States", within the Canada-US Project, Blueprint for Canada-US Engagement under a New Administration, Centre for Trade Policy and Law, Carleton University, 2008 text available at http://www.carleton.ca/ctpl/conferences (accessed 26 February 2009), at 8 and O.R. Young, "Arctic Governance: Emerging Challenges - New Opportunities", presentation at the Alliance for Liberals and Democrats for Europe (ALDE) Seminar Arctic Governance in a global world: is it time for an Arctic Charter?, 7 May 2008 (hand-outs available at http://www.alde.eu (accessed 26 February 2009). In this presentation, Young does not repeat his earlier idea of establishing a Commission on Arctic Sustainable Development (CASD) modeled on the World Commission on Environment and Development (see O.R. Young, Arctic Governance: Preparing for the Next Phase, paper presented at Fifth Conference 
A pertinent question is nevertheless how the Ilulissat Declaration should be interpreted in this regard: does it draw a line in the sand or is it an opening bid in the initial stages of the ongoing debate on reform? The latter could certainly turn out to be the better interpretation, in particular if the primary purpose of the cited phrase is to reject reform along the lines of the Antarctic Treaty and if existing and newly established sectoral arrangements do not succeed in adequate coordination and coordination. ${ }^{140}$ The pace of change in the Arctic is likely to be a crucial factor in that regard.

\section{Conclusions}

The unprecedented pace of change that the Arctic is currently experiencing makes it very difficult to argue that the current international legal and policy framework for Arctic fisheries conservation and management is adequate for responding to the huge challenges that lie ahead. This article identifies a number of governance and regulatory gaps in this framework as well as in national regulation and offers various options for addressing them. Some initial steps towards one of these options - namely a declaration on new and existing fisheries in the Arctic Ocean - are already underway. Such a declaration would function as a minimum level of protection - even though a non-legally binding one - in case new fishing opportunities arise earlier than foreseen, in the absence of the necessary scientific information or with potentially higher risks to the protection and preservation of the marine environment, marine biodiversity and the rights and interests of Arctic indigenous peoples. The pace of change will also determine when negotiations for an Arctic RFMO or Arrangement should commence.

While assuming that international fisheries conservation and management in the Arctic marine area will pursue an ecosystem approach to fisheries (EAF), sooner or later such sectoral approaches will have to be aligned with the governance and regulation of other human activities. Such alignment will then eventually lead to the pursuance of integrated, cross-sectoral ecosystembased oceans management in the Arctic. There are nevertheless diverging pathways towards that ultimate objective. They range from coordination and cooperation between individual states, entities and existing institutions to the

of Parliamentarians of the Arctic Region (2002) (text available at http://www.arcticparl.org (accessed 26 February 2009).

${ }^{140}$ See also Young's 2002 paper, note 139 supra, where he identifies "the prospect that individual elements of the Arctic's institutional complex will collide with one another or work at cross purposes" as one of three main concerns. 
establishment of a new body or the transformation of the Arctic Council by means of a regional legally binding instrument for the governance and regulation of the (marine) Arctic. The pathways at the latter end of the spectrum are obviously much more ambitious than those 'business-as-usual' pathways at the former end. Decision-makers should nevertheless carefully consider if business-as-usual attitudes are justifiable under the current unprecedented circumstances. They should also not lose sight of the stature in the international community of Arctic states and other states and entities that have recently expressed a willingness to become closely involved in Arctic governance and regulation. They should certainly also not ignore that unprecedented challenges can also offer unprecedented opportunities for reform. Grasping such opportunities could give the Arctic Ocean a pioneering role in regional oceans governance and regulation. 